\title{
Introduction: Reading and Writing in Prison
}

\author{
Anne Schwan
}

The aims of this special issue on 'Reading and Writing in Prison' are twofold: to insist on the cultural significance of paying serious critical attention to the genre of prison writing beyond canonical authors (such as Oscar Wilde) and to showcase reading and writing in prison as a space for radical pedagogy and social transformation - potential transformation not only for those 'inside' but also those going into prisons as facilitators, be they creative practitioners, academics, or university students.

Prison (auto)biography, and reading and writing in prison more broadly speaking, are burgeoning areas of research that lend themselves to fruitful conversations across disciplinary boundaries. ${ }^{1}$ As prison populations are reaching record levels, debates around reading and writing in penal institutions are receiving renewed attention by scholars and policymakers. Scholars and practitioners alike have long been arguing that opportunities for reading and writing in prisons can become a dignifying tool for prisoners to re-evaluate and reconstruct their lives, with positive impact on recidivism rates and thus society as a whole. Others, critical of the ideological agenda of the rhetoric of 'rehabilitation', primarily see literate activities as a space that can allow for explorations of social problems and structures of inequalities and instill a desire for radical change, rather than compliance.

In the North American Humanities, prison writing has become a core part of many curricula, which also include so-called servicelearning projects involving student-inmate reading groups or jointly taught classes. Educational institutions running such projects range from small liberal arts colleges to large universities. High-profile journals such as the Modern Language Association of America's $P M L A$ have dedicated recent issues to 'Prisons, Activism, and the Academy: Incarceration and Social Justice'. ${ }^{2}$ 
Similarly, creative practitioners across the UK have been going into prisons for years (in some cases as long-term employees of prison education providers) to run reading groups, creative writing or drama workshops, with new edited anthologies emerging from such work. ${ }^{3}$ Some, like Caspar Walsh, regular contributor to the Guardian and himself a former prisoner, have worked hard to establish new institutional settings, like the young offender charity 'Write to Freedom' that offers sustained support and inspiration through creative writing, during imprisonment and after release. ${ }^{4}$

UK universities, too, are increasingly beginning to play a role in forging relationships with prisons to offer opportunities for prisoners in the areas of reading and writing. Jenny Hartley and Sarah Turvey, both in the University of Roehampton's English Department, have been facilitating prisoner reading groups in a number of English institutions, while I have just initiated a new partnership between the English programme at Edinburgh Napier University, the Scottish Prison Service (SPS), and Carnegie College, one of the SPS' main learning providers, that will see university students enter into a local prison to engage in literacy activities. ${ }^{5}$ Growing academic interest in the genre of prison writing, reading, and arts-related practices in prison, from both a contemporary and historical viewpoint, is also evidenced by the fact that in 2010 alone, three UK conferences were dedicated to these issues. ${ }^{6}$

On a practical level, promoting reading and writing activities in prisons means negotiating a complex set of expectations by all the stakeholders involved, including the wider public, who are often assumed to prefer punishment over " "fun" activities' and rehabilitation. ${ }^{7}$ Briege Nugent and Nancy Loucks note in a recent article on 'creative rehabilitation' in The Howard Journal of Criminal Justice that while the positive impact of arts-related activities in prisons is now accepted as a given in a number of countries, such recognition competes against pressures of overcrowding and understaffing as prison populations continue to rise at a moment of simultaneous budget cuts. Writing with particular reference to the Scottish context, Nugent and Loucks point out that art projects in most prisons are "not underpinned by strategic policy and sit[s] as an "add on" to the core delivery objective of security' and largely depend on the work of dedicated individuals (366). Although educational provision in European prisons, including the UK, may be more comprehensive than in other nations such as the US, economic restrictions at a time 
of austerity require particular determination and resourcefulness on the part of practitioners and scholar-activists.

The articles in this special issue explore prison narratives and reading and writing practices in the US and England in their wider socio-historical context. Many of the pieces consciously attempt to bridge the gap between theory and practice, thinking about the challenges of prison literacy activism through a theoretical lens. Prisoners' voices are central to all pieces, and individual authors negotiate the fine line between appropriation and 'giving voice' in different, and often explicit, ways. In spite of differences in outlook and disciplinary perspective, all articles share a belief in the power of reading and writing in prison, even if individual authors' views on the functions and aims of such activities diverge. Beyond the value of individual contributions, then, this special issue as a whole offers important conversations about the need for scholarly and activist engagement with reading and writing in prison, the value and limits of such activities, and the genre of prison writing itself, as well as the benefits and challenges involved in negotiations between 'theory' and 'practice' and across institutions (such as universities and prisons).

Ed Wiltse's 'Doing Time in College: Student-Prisoner Reading Groups and the Object(s) of Literary Study' considers the challenges and rewards of a decade-long project in upstate New York, bringing together university students and prisoners to discuss crime fiction at weekly 'book club' meetings in jail. Drawing on research into reading practices, Wiltse shows how participants respond to their encounters with texts and other group members and how prisoners 'become subjects of literary study' rather than 'the potential objects of knowledge in those jail classrooms' (21). Joe Lockard and Sherry Rankins-Robertson's 'The Right to Education, Prison-University Partnerships, and Online Writing Pedagogy in the US' surveys the curtailment of educational opportunities in US penal institutions over recent years and showcases the role of English Departments in filling in the gaps of official provision. Drawing attention to the potential of online technologies, the authors introduce their 'Prison Writing \& Critical Practice' internship at Arizona State University, run in collaboration with the Pen Project at the New Mexico Corrections Department. The project trains student interns to provide detailed online feedback on prisoner writing, realizing education as a human right for prisoners while 'spur[ring] new activism within university communities' (35). Tobi Jacobi’s 'Speaking Out for Social Justice: 
The Problems and Possibilities of US Women's Prison and Jail Writing Workshops' focuses on the particular challenges of incarcerated women, based on her experience of teaching writing workshops in northern Colorado. Placing her discussion in the context of the prison abolition movement, Jacobi argues that it is important for practitioners to acknowledge tactical complicity within penal institutions while insisting that writing programmes can pave the way for 'more radical growth by individuals and writing groups that will contribute to a larger social movement' (48). Breea C. Willingham, in 'Black Women's Prison Narratives and the Intersection of Race, Gender, and Sexuality in US Prisons', addresses black women's prison literature through the lens of black feminist thought. Willingham argues that African American women's prison narratives deserve wider critical attention as they 'offer a unique insight into interlocking patterns of oppression' (56) that lead to black women's incarceration, while fulfilling important healing functions on an individual level. Writing about English prisons, Josie Billington explores the therapeutic value of reading practices in closed institutions in "Reading for Life": Prison Reading Groups in Practice and Theory'. Through a framework bridging humanities and (social) scientific research, Billington discusses testimonies and other practice-based evidence around the shared reading of 'serious' literature in prisons, in a wider context of reader response theories and official guidelines on the mental health needs of prisoners. Melissa Dearey, Bethanie Petty, Brett Thompson, Clinton R. Lear, Stephanie Gadsby and Donna Gibbs make a case for the value of prisoner life writing in the discipline of criminology, and for wider public debate, in 'Prison(er) Auto/biography, "True Crime", and Teaching, Learning, and Research in Criminology'. Authored by a teacher of criminology and a group of her students at an English university, the article surveys the role of prisoner life writing in the discipline, challenging its marginalization. Simon Rolston, in 'Conversion and the Story of the American Prison', asks why 'the conversion narrative [is] a normalised way to experience (or to narrativise the experience of) incarceration' (105). Reading a number of US prison narratives in the context of 'the rehabilitation era', Rolston challenges assumptions that prisoners" autobiographies "write back to power"” and argues that they instead 'invoke competing discourses that contest but also reinforce the ideology of the American prison system' (106). 
Reading these individual articles with and against one another will make for productive debate on disciplinary boundaries and paradigms, from literary and cultural studies via composition studies, to the medical humanities and criminology. Collectively, these articles make a compelling case for why, at the current moment, research and activism around reading and writing in prisons matter more than ever.

\section{Acknowledgement}

I gratefully acknowledge support through an Arts and Humanities Research Council (AHRC) Fellowship (Early Career) which allowed me to dedicate time to the preparation of this special issue.

\section{Notes}

1. For some recent examples of research on prison writing and reading practices from a historical and contemporary perspective, see for instance Rosalind Crone, 'Attempts to (Re) shape Common Reading Habits: Bible Reading on the Nineteenth-century Convict Ship', in A Return to the Common Reader: Print Culture and the Novel, 1850-1900, ed. Beth Palmer and Adelene Buckland (Aldershot: Ashgate, 2011), 103-120; Lucy Frost, 'The Politics of Writing Convict Lives: Academic Research, State Archives and Family History', Life Writing 8.1 (2011): 19-33; Jenny Hartley, 'Reading in Gaol', in A Return to the Common Reader, ed. Beth Palmer and Adelene Buckland, 87-102; Jason Haslam, Fitting Sentences: Identity in Nineteenth- and Twentieth-Century Prison Narratives (Toronto: Toronto University Press, 2005); Megan Sweeney, Reading Is My Window: Books and the Art of Reading in Women's Prisons (Chapel Hill: The University of North Carolina Press, 2010); Helen Rogers, 'The Way to Jerusalem: Reading, Writing and Reform in an Early Victorian Gaol', Past and Present 205 (November 2009): 71-104.

2. PMLA 123.3 (May 2008).

3. See for instance Kate Hendry, ed., The Poem Goes to Prison: Poems Chosen by Readers at HMP Barlinnie (Edinburgh: Scottish Poetry Library, 2010).

4. http://writetofreedom.co.uk/. Accessed 30 September 2011. See also Caspar Walsh's autobiography Criminal (London: Headline Review, 2008).

5. See Jenny Hartley and Sarah Turvey, 'What Can a Book Do Behind Bars?', The Reader 32 (Winter 2008): 60-68; Jenny Hartley and Sarah Turvey, 'Reading Together: The Role of the Reading Group Inside Prison', Prison Service Journal 183 (May 2009): 27-32.

6. 'Arts in Prisons: Their Impact and Potential', Edinburgh University, 12-14 February 2010; 'Reading and Writing in Prison', Edinburgh Napier University, 4-5 June 2010; 'A Colloquium on Prison Narratives', University of Northampton, 28 June 2010.

7. Briege Nugent and Nancy Loucks, 'The Arts and Prisoners: Experiences of Creative Rehabilitation', The Howard Journal of Criminal Justice 50.4 (2011): 356-370 (366). 